\title{
Pemanfaatan Dana Desa Bagi Warga Terdampak Pandemi Covid-19 (Studi Desa Bohar, Kecamatan Taman, Kabupaten Sidoarjo)
}

\author{
Billa Fanisa \\ S1 Ilmu Administrasi Negara, Fakultas Ilmu Sosial dan Hukum, Universitas Negeri Surabaya dan \\ billafanisa@gmail.com \\ Muhammad Farid Ma'ruf \\ S1 Ilmu Administrasi Negara, Fakultas Ilmu Sosial dan Hukum, Universitas Negeri Surabaya dan \\ muhammadfarid@unesa.ac.id
}

\begin{abstract}
Abstrak
Penelitian ini dilatarbelakangi oleh menyebarnya Covid-19 yang berdampak besar pada banyak sektor yang ada di Indonesia, salah satunya ekonomi. Untuk menaggapi permasalahan tersebut, pemerintah Indonesia berusaha untuk menstabilkan perekonomian Indonesia dengan mengeluarkan kebijakan Perubahan Prioritas Penggunaan Dana Desa melalui Permendesa Nomor 6 Tahun 2020. Sidoarjo menjadi urutan kedua sebagai kabupaten di Jawa Timur dengan pasien Covid-19 terbanyak setelah Surabaya. Desa Bohar terletak di Kabupaten Sidoarjo merupakan kawasan dengan resiko Covid-19 sedang. Maka dari itu penelitian ini bertujuan untuk mengetahui Pemanfaatan Dana Desa Bagi Warga Terdampak Pandemi Covid-19 di Desa Bohar, Kecamatan Taman, Kabupaten Sidoarjo. Untuk mencapai tujuan tersebut digunakan metode pnelitian kualitatif dengan pendektaan deskriptif. Pengumpulan data dilakuaan dengan observaasi, wawancara, dan dokumentasi. Adapun fokus dalam penelitian ini adalah Penggunaan Dana Desa yang tercantum dalam Permendesa Nomor 6 Tahun 2020 tentang Perubahan PPTD Nomor 11 Tahun 2019 meliputi Penggunaan Dana Desa untuk Pencegahan dan Penanganan Covid-19, Penggunaan Dana Desa untuk Padat Kraya Tunai Desa (PKTD), dan Penggunan Dana Desa untuk Bantuan Langsuug Tunai (BLT). Hasil penelitian menunjukkan bahwa penggunaan dana desa untuk pencegahan dan penanganan Covid-19 masih belum maksimal. Masih banyak kegiatan yang tidak mematuhi protokol kesehatan sehingga tujuan pencegahan Covid-19 belum tercapai. Selanjutnya penggunaan dana desa untuk PKTD juga belum dilaksanakan dengan baik karena pemilihan pekerja PKTD oleh Pemdes Bohar bukan berdasarkan data keluarga miskin ataupun pengangguran sehingga sasaran tidak tepat. Sedangkan penggunaan dana desa untuk BLT sudah dilakukan dengan baik karena data yang dipakai merupakan data baru sehingga tepat sasaran.
\end{abstract}

Kata Kunci: Dana Desa, Covid-19, Prioritas Anggaran

\begin{abstract}
This research was motivated by spread of Covid-19 which had a huge impact on economic sector in Indonesia. Therefore Indonesian government is trying to stabilize economy by issuing a policy to change priority for use of village funds through Permendesa Numer 6 of 2020. Sidoarjo is second place as district with most Covid-19 patients after Surabaya in East Java. Bohar Village, located in Sidoarjo Regency, is an area with moderate Covid-19 risk. Therefore this research aims to determine utilizition of village funds for Covid-19 Pandemic in Bohar Village, Sidoarjo District. To achieve this purpose, qualitative research is using with descriptive data. Observation, interview, and documentation were used as technique of data collection. The focus in this research is Use of Village Funds listed in Permendesa Number 6 of 2020 which include Use of Village Funds for Prevention and Handling of Covid-19, Use of Village Funds for Village Cash Work Intensive (PKTD), and Use Village Fund for Direct Cash Assistance (BLT). The results: Use of Village Funds for Covid-19 Prevention and Handling is still not optimal because many activities that don't comply with health protocols so that purpose of preventing Covid-19 hasn't been achieved. Furthermore, for PKTD hasn't been implemented properly because selection of PKTD workers by the Bohar Village Government isn't based on data of poor families or unemployment so that the target isn't right. Meanwhile, BLT has been carried out well because data used is new data so that target is right.
\end{abstract}

Keywords: Village Funds, Covid-19, Budget Priorities 


\section{PENDAHULUAN}

Pada tanggal 31 Desember 2019 World Health Organization melaporkan sebuah wabah yang menyerang area paru-paru yang disebut dengan Syndrome Coronavirus-2 (SARS-CoV-2) atau yang sering disebut Covid-19 ditemukan di Kota Wuhan, Provinsi Hubei, China. Djalante dkk (2020:1) mengatakan bahwa Covid19 ditetapkan menjadi pandemi global oleh WHO dikarenakan penyebaran yang cepat hingga ke seluruh negara dan berdampak sangat besar di berbagai sektor.

Untuk menekan penyebaran Covid-19, banyak negara yang menerapkan social distancing seperti belajar dari rumah, bekerja dari rumah, penutupan tempat publik hingga larangan untuk penerbangan. Donthu \& Gustafsson (2020:284) mengatakan bahwa penerapan social distancing mengakibatkan banyak perusahaan dari berbagai sektor yang mengalami defisit bahkan banyak juga yang terpaksa ditutup karena merugi. Hal tersebut juga terjadi di Indonesia.

Menurut Gugus Tugas Percepatan Penanganan Covid19 (2020) tanggal 2 Maret 2020 dengan 2 pasien positif menjadi kasus Covid-19 pertama di Indonesia dan terus mengalami peningkatan hingga saat ini. Per tanggal 22 September 2020 pasien Covid-19 di Indonesia berjumlah 252.923 orang, 184.298 orang sembuh, dan yang meninggal sebanyak 9.837 orang. Sehingga untuk menekan angka peningkatan Covid-19 Pemerintah Indonesia juga memberlakukan social distancing. Pemberlakuan social distancing atau biasa disebut Pembatsan Sosial Bersakala Besar (PSBB) diatur dalam Peraturan Pemerintah Nomor 21 Tahun 2020 tentang PSBB dalam rangka percepataan penanganan Covid-19 yang kemudian diperjelas dengan Peraturan Kementerian Kesehatan Nomor 9 Tahun 2020 tentang Pedoman PSBB.

Menurut Susilawati, dkk (2020:1148) PSBB yang diberlakukan berdampak pada berbagai sektor yang ada di Indonesia mulai dari pariwisata, pendidikan, bahkan ekonomi. Pakpahan (2020) juga menyebutkan bahwa dari sektor ekonomi banyak usaha makro dan usaha mikro (UMKM) yang merugi bahkan tidak sedikit yang tutup usaha. Hal ini juga berdampak pada pengangguran yang semakin bertambah. Menurut Putri (2020:1) pengangguran yang terverifikasi berjumlah 1,8 juta orang dan 1,2 juta orang masih belum terverifikasi. Diperjelas dengan pendapat Fahri, Jalil, \& Kasnelly (2020:56) yang mengatakan masih adanya kemungkinan jumlah pengangguran bertambah untuk skala moderat sekitar 7,7 $\%$ dan untuk skala berat sekita 10, 3\%.

Menanggapi permasalahn tersebut pemerintah Indonesia mengeluarkan Peraturan Pemerintah Pengganti Undang-Undang (Perpu) Nomor 1 Tahun 2020 tentang Kebijakaan Keuangan Negara dan Stabiiltas Sistem
Keuangan untuk Penanggnan Pandemi Covid-19 dan/atau dalam Rangka Manghaadapi Ancaamn yang Membahayakan Perkonomian Nasional atau Stabilitas Sistem Keuangaan yang menjelaskan bahwa dlaam menghadapi pandemi pelaksanaan Anggaran Pendapatn dan Belanja Negara ialah dengan manajemen pandemi Covid-19 dan manghadapi ancaman yang membahayakan perkonomian nasional. Perpu Nomor 1 Tahun 2020 juga menjelaskan mnegnai pemberian kewenangan kepada pemerintah daerah untuk melakukan prioritas anggaran (refocussing dan realokasi). Prioritas anggaran diserahkan kepada setiap desa yang akan di koordinasikan dengan pemerintah daerahnya masingmasing. Hal ini mengacu pada Peraturan Menteri Dalam Negeri Tahun 2020 tentang Percepataan Penangnan Covid-19 di Lingkunga Pemerintah Daerah.

Guna memperjelas realokasi dan refocussing Kementerian Desa mengeluarkan kebijakan melalui Peraturan Menteri Desa, Pembangunan Daerah Tertinggal, dan Transmigrasi Nomor 6 Tahun 2020 tentang Perubahan PPDT Nomor 11 Tahun 2019. Adapun perubahan yang dimaksud diantaranya perubahan prioritas penggunaan dana desa yang semula untuk pembangunan desa dan pemberdayaan masyarakat akan dialihkan untuk pencegahan dan penganan Covid-19, padat karya tunai desa (PKTD), dan bantuan langsung tunai (BLT). Menurut Aminah \& Sari (2018:28) program yang diprioritaskan dalam penggunaan dana desa tahun 2019 seperti program unggulan kawasan pedesaan, penguatan BUMDes, lembung desa, dan pnyelenggaraan acara keolahragaan desa. Mengenai realokasi dan refocussing penggunaan dana desa, Utama, Pertiwi, \& Muda (2020:366) mengatakan bahwa realokasi dan refocussing dapat dilakukan dengan menunda pembangunan atau pembelian barang yang tidak mendesak, perjalanan dinas, pengadaan kegiatan pertemuan.

Hal di atas diperjelas dengan Surat Edaran Kemendes Nomor 8 Tahun 2020 tentng Desa Tangaap Covid-19 dan PKTD dan Peraturan Menteri Keuangan Nomor 40 Tahun 2020 yang menjadi fokus penelitian. SE Kemendes Nomor 8 Tahun 2020 menyebutkan bahwa pembentukan Desa Tanggap Covid-19 yang berisikan relawan terstruktur dilakukan untuk pencegahan Covid19. Relawan Covid-19 ini memiliki tugas antara lain: melakukan edukasi dan sosialisasi mengenai informasi yang berkaitan dengan Covid-19, pendataan penduduk yang rentan sakit, melakukan penyemprotan disenfektan dan penyediaan alat kesehatan. Kemudian PKDT merupakan program yang memberdayakan masyarakat guna meningkatkan kesejahteraan masyrakat khususnya masyarakat miskin atau pengangguran. Lestari, dkk (2018:10) berpendapat bahwa kesejahteraan sangat erat 
kaitannya dengan kemiskinan. Menurut Sekarsari \& Rosida (2019:40) pengangguran adalah ukuran dari kegiatan produktif yakni menghasilkan barang atau jasa. Untuk pemberian upah akan diberikan setiap hari dan diwajibkan untuk selalu memathuhi protokol kesehatan. Peraturan Menteri Keuangan Nomor 40 Tahun 2020 menjelaskan bahwa desa diwajibkan untuk memberikan BLT selama tiga bulan dengan bantuan sebesar Rp 600.000 setiap bulannya. Untuk penerima BLT ini diberikan kepada masyarakat kurang mampu yang bukan penerima program bantuan dari pemerintah lainnya seperti Progran Keluarga Harapan (PKH), Kartu Sembako, Kartu Praa Kerja, dan lain-lain.

Perubahan prioritas penggunaan dana desa dilakukan karena desa sendiri merupakan pemerintahan yang paling dekat dengan masyarakat sehingga lebih paham akan permasalahan yang terjadi di masyarakat. Dengan demikian pengunaan dana desa akan menjadi lebih efektif dan efisien. Adapun pengertian desa merupakan kesatuan masyarakat hukum yang memiliki batas wilayah dan berwenang untuk mengatur urusan pemerintahan, kepentingan masyarakat setempat berdasarkan prakarsa masyarakat, hak asal usul atau hak tradisional yang diakui dan dihormati hal ini tercantum dalam UndangUndang Nomor 6 Tahun 2014 tentang Desa. UU Nomor 6 Tahun 2014 juga menjelaskan bahwa pemerintah desa terdiri dari kepala desa yang kemudian dibantu oleh perangkat desa. Desa memiliki kewenangan dalam penyelenggaran pemerintahan desa, pembangunan desa, dan pemberdayaan masyarakat. Sehubungan dengan penelitian Mahmuddin \& Banurea (2018) mengatakan bahwa pemerintah desa juga bertanggung jawab untuk memenuhi kebutuhan masyarakat dengan menggunakan dana desa guna meningkatkan kesejahteraan masyrakatnya.

Dana desa merupakan dana yang bersumber dari APBN untuk desa yang akan di tranfer melalui APBD dan digunakan untuk mendanai penyelenggaran pemerintahan desa, pembangunan desa, dan pemberdayaan masyarakat, hal diatas tercantum pada Permendesa Nomor 6 Tahun 2020. Permendesa Nomor 6 Tahun 2020 juga menjelaskan bahwa Dana Desa sebagai bagian pendapatan desa merupakan milik desa, sehingga pengelolaannya merupakan kewenangan desa. Adapun asas-asas pengelolaan dana desa menurut Permendagri Nomro 113 Tahun 2014 meliputi transparan yang berarti keterbukaan pemdes agar diketahui masyarakat, akuntabel yang berarti bertanggungjawab ats pengelolaan anggaran, partisipatif yang berarti pemberian kesempatan bagi masyrakat untuk ikut dalam proses pengelolaan dana desa, serta dilakukan dengan tertib dan disiplin anggaran yang berarti pengelolaan harus sesuai dengan waktu yang ditetapkan dan sesua sasaran.
Sehubungan dengan penelitian Hidayati dalam Binar, dkk (2020:97) berpendapat bahwa dana desa akan dikelola oleh pemerintah desa sehingga dana desa yang akan digunakan lebih efektif dan efisien dan tujuan adanya dana desa tercapai. Dana desa yang dikelola oleh pemerintah desa itu sendiri merupakaan pemenuhan hak otonomi desa yang mana kegiatan otonomi desa tersebut dapat meningkatkan kesejahteraan masyarakatnya. Selain itu, penelitian Dian, Tiara Rama \& Ma'ruf, Muhammad Farid (2019) menjelaskan bahwa dengan pelaksanaan otonomi desa, desa akan menjadi mandiri tanpa harus bergantung pada pemerintah pusat. Hal ini didukung oleh penelitian Karimah, Saleh, \& Wanusmawatie (2014:598) yang mengatakan jika anggaran dana desa dikelola dengan baik dan jujur maka kegiatan otonomi desa akan terlihat jelas. Selaras dengan pendapat Waluyo (dalam Astuty, Elgia; Fanida, 2013) yang mengatakan bahwa pengelolaan keuangan daerah yang efektif dan efisien maka pelaksanaan otonomi daerah akan semakin mencapai keberhasilan.

Perubahan proritas penggunaan dana desa juga dilakukan oleh permerintah Desa Bohar. Desa Bohar terletak di Kabupaten Sidoarjo yang merupakan kabupaten di Jatim dengan kasus Covid-19 tertinggi setelah Surabaya menjadikan Desa Bohar lebih waspada dan seefektif mungkin dalam penggunaan dana desa. Berdasarkan wawancara awal dengan Pak Kusnan selaku Sekretaris Desa Bohar mengatakan bahwa sejauh ini pasien Covid-19 yang positif 2 orang dan sedang dirawat di rumah sakit, 4 orang melakukan isolasi mandiri, 6 orang meninggal, dan 13 orang sudah dinyatakan sembuh. Desa Bohar menerima anggaran dana desa sebesar Rp 848.182.000 yang awalnya semua anggaran diprioritaskan untuk pembangunan desa. Namun, setelah pandemi Covid-19 Desa Bohar mengajukan perubahan Rencana Anggaran Biaya (RAB) pada 8 April 2020 yang menganggarkan Rp 398.042.000 untuk pencegahan dan penanganan Covid-19. Mengacu pada Permendesa Nomor 6 Tahun 2020, Penggunaan dana desa untuk pencegahan Covid-19 di Desa Bohar membentukan 6 tim relawan Covid-19 yang dibagi ke 6 dusun yang ada di Desa Bohar. Pembagian BLT sebesar Rp 600.000 kepada 133 keluarga pada bulan April, Mei, dan Juni. Dan Program PKTD dilakukan dengan memberdayakan masyarakat desa untuk menjadi tim relawan Covid-19 yang berjumlah 36 orang. Namun, menurut Bu Narti selaku salah satu masyarakat Desa Bohar mengatakan bahwa pekerja PKTD tidak semua berasal dari keluarga miskin ataupun pengangguran. Padahal menurut Permendesa Nomor 6 Tahun 2020 disebutkan bahwa masyarakat yang diberdayakan dalam program PKTD diharuskan berasal dari keluarga miskin atau pengangguran. Sehingga melihat permasalahan tersebut, peneliti tertarik untuk 
melakukan penelitian mengenai pemanfaatan dana desa bagi warga terdampak pandemi Covid-19 di Desa Bohar, Kecamatan Taman, Kabupaten Sidoarjo.

\section{METODE}

Penelitian ini merupakan jenis penelitian kualitatif dengan menggunakan pendekatan deskriptif agar memperolah pemaparan yang objektif dan mengetahui permasalahan yang terjadi mengenai pemanfaatan dana desa bagi warga terdampak Covid-19 di Desa Bohar, Kecamatan Taman, Kabupaten Sidoarjo.

Penelitian ini akan memfokuskan pada kajian prioritas penggunaan dana desa yang diatur dalam Peraturan Menteri Desa, Pembangunan Daerah Tertinggal Nomor 6 Tahun 2020 meliputi:

1. Pemanfaatan Dana Desa dalam Operasional Pencegahan dan Penanganan Covid-19

Dalam operasional pencegahan dan penanganan Covid-19, dana desa dimanfaatkan dengan membentuk tim relawan yang berstruktur meliputi ketua, wakil ketua, anggota, dan pendamping. Adapun tugas-tugas yang harus dijalankan yakni tindakan pencegahan dan penanganan. Tindakan pencegahan Covid-19 meliputi:

a. Mendata penduduk yang rentan sakit

b. Mengidentifikasi fasilitas-fasilitas desa yang dapat dijadikan tempat isolasi

c. Melakukan penyemprotan disinfektan dan penyediaan tempat cuci tangan

d. Menyediakan alat kesehatan

e. Menyediakan informasi terkait penanganan Covid19 seperti nomor telepon rumah sakit rujukan

f. Melakukan deteksi dini dengan pencatatan keluar masuk tamu

g. Mendirikan Pos Jaga Desa

h. Memastikan tidak ada kegiatan yang berkumpul

Adapun tindakan penanganan Covid-19, diantaranya:

a. Bekerja sama dengan rumah sakit rujukan atau puskesmas setempat

b. Penyiapan ruang isolasi

c. Merekomendasikan warga yang pulang dari daerah terdampak Covid-19 untuk mengisolasikan diri

d. Membantu menyiapkan logistik untuk warga yang masuk ruang isolasi

e. Menghubungi petugas medis atau BPBD untuk tindak lanjut warga yang masuk ruang isolasi

2. Pemanfaatan Dana Desa dalam Padat Karya Tunai Desa (PKTD)

Dana desa dimanfaatkan dengan pola PKTD melalui pengelolaan swakelola dan pendayagunaan sumberdaya manusia desa. Pekerja PKTD diprioritaskan bagi keluarga miskin atau pengangguran yang diupah harian. Pelaksanaan PKTD juga diharuskan untuk mengikuti protokol kesehatan.

3. Pemanfaatan Dana Desa dalam Bantuan Langsung Tunai (BLT)

Dana desa dimanfaatkan untuk memberikan BLT kepada keluarga miskin yang bukan penerima program $\mathrm{PKH}$ atau bantuan pemerintah lainnya. Pemberian BLT dilakukan selama tiga bulan terhitung sejak bulan April 2020 sebesar Rp 600.000 per keluarga. Untuk mekanisme penyalurannya dilakukan dengan cara non- tunai. Pendataan penerima BLT dilakukan oleh tim relawan dan berkoordinasi dengan RT dan RW yang kemudian akan di diskusikan melalui musyawarah desa. Adapun. Metode perhitungan dana desa untuk BLT sebagai berikut:

Tabel 1. Metode Perhitungan Dana Desa

\begin{tabular}{|c|c|}
\hline Jumah Dana Desa & Maks. Prosentase \\
\hline$<\operatorname{Rp~} 800.000 .000$ & $25 \%$ \\
\hline $\operatorname{Rp} 800.000 .000$ & $30 \%$ \\
\hline$>\operatorname{Rp~} 800.000 .000$ & $35 \%$ \\
\hline
\end{tabular}

(Sumber: Kementerian Desa, Pembangunan Daerah

Tertinggal, dan Transmigrasi, 2020)

Informan dalam penelitian meliputi perangkat desa, tim relawan Covid-19, dan masyarakat khususnya yang menerima bantuan sosial selama pandemi Covid-19 berlangsung. Adapun metode yang digunkaan untuk pengumpulan data diantaranya dengan wawancara, observssi, dan dokumentasi. Dan analisis data yang digunakan meliputi reduksi data, penyajian data, dan penarikan kesimpulan (Milles and Huberman dalam Sugiyono, 2015).

\section{HASIL DAN PEMBAHASAN}

\section{Pemanfaatan Dana Desa dalam Operasional Pencegahan dan Penanganan Covid-19}

Bentuk dari pemanfaatan dana desa untuk operasional pencegahan dan penangganan Covid-19 menurut Permendesa Nomor 6 Tahun 2020 adalah dengan membentuk tim relawan Covid-19. Di Desa Bohar tim relawan Covid-19 dibentuk pada tanggal 30 Maret 2020. Pembiayaan yang diperlukan untuk pembentuk tim relawan Covid-19 ialah berupa pengadaan peralatan kesehatan seperti disenfektan, masker, termometer, baju azmat, dan face shield. Untuk operasional pencegahan dan penanganan Covid-19, Desa Bohar menganggarkan Rp 64.053.440. Berikut merupakan Surat Keputusan terbentuknya tim relawan Covid-19 di Desa Bohar: 


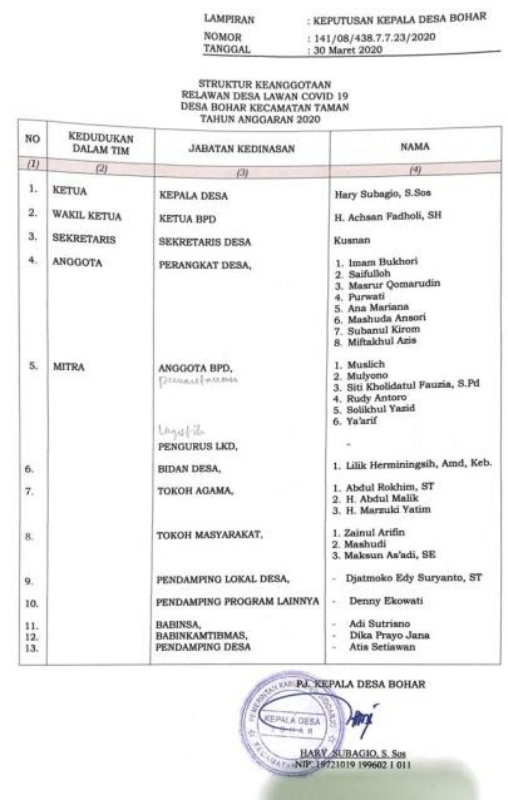

Gambar 1. Surat Keputusan Tim Relawan Covid-19 Desa Bohar

(Sumber : LPJ Tim Relawan Covid-19, 2020)

Berdasarkan gambar diatas tim relawan Covid-19 yang ada di Indonesia sudah sesuai dengan yang ditentukan dengan Peremndes Nomor 6 Tahun 2020. Berdasarkan keterangan dari Pak Kusnan selaku sekdes Bohar, tim relawan juga bekerja sama dengan karang taruna dan remas yang ada di Desa Bohar.

Adapun tugas-tugas dari tim relawan Covid-19 dalam tindakan pencegahan diantaranya Pertama memberikan edukasi perihal informasi mengenai Covid-19 mulai dari gejala, cara penularan, maupun cara-cara pencegahannya. Didesa Bohar pemberian edukasi atau sosialisasi mengenai Covid-19 masih sangatlah kurang. Berdasarkan pengamatan peneliti di Desa Bohar tidak ada benner ataupun spanduk yang berisikan informasi mengenai Covid-19. Hal ini didukung oleh wawancara dengan Pak Kusnan sebagai berikut:

"Edukasi atau sosialisasinya tidak dilakukan secara langsung kepada masyrakat. Edukasi hanya diterima oleh tim relawan dari tim rumah sakit rujukan dan puskesmas yang bekerja sama. Masyarakat yang dinyatakan reaktif ataupun positis Covid-19 saja yang akan diberikan penjelasan tentang Covid19." (Wawancara pada 8 Desember 2020)

Kedua melakukan pendataan penduduk rentan sakit, orang dengan penyakit menahun atau penyakit kronis lainnya. Di Desa Bohar, pendataan diserahkan kepada bidan desa yang kemudian akan dilaporkan ke desa. Hal ini didukung oleh pernyataan dari Pak Kusnan selaku skretarid Desa Bohar sebagi berikut:

\begin{abstract}
"Desa Bohar memasrahkan pendataan penduduk yang rentan sakit kepada Bu Lilik (bidan Desa Bohar). Setelah pendataan selesai Bu Lilik laporan ke desa mana saja yang rentan." (Wawancara pada 8 Desember 2020)
\end{abstract}

Hal diatas diperjelas oleh keterangan dari $\mathrm{Bu}$ Lilik selaku bidan desa di Desa Bohar sebagai berikut:
"Pendataan penduduk rentan sakit tidak dilakukan seperti sensus yang datang ke rumah satu-satu, tapi secara lisan, dari mulut ke mulut kalau ada yang keluarga atau tetangganya sakit silahkan melapor." (Wawancara pada 12 Desember 2020)

Hingga saat ini masih sedikit pelaporan yang masukkhususnya masyarakat yang tinggal di bagian pedesaan. Hal tersebut dikarenakan kurangnya kesadaran masyrakat mengenai Covid-19. Adapun wawancara dengan Bu Lilik sebagai berikut:

"Ada perbedaan masyarakat perumahan sama desa. Masyarakat perumahan sudah pahan dan sadar tentang bahaya Covid-19 jadi banyak yang lapor. Tapi masyarakat desa yang susah, alasannya takut dikucilkan" (Wawancara pada 12 Desember 2020)

Ketiga mengidentifikasi fasilitas yang dimiliki oleh desa untuk di ubah menjadi ruang isolasi. berdasarkan pengamatan peneliti kantor desa Bohar memiliki ruang yang terbatas sehingga untuk menyediakan tempat isolasi tidak memungkinkan. Hal ini didukung oleh wawancara dengan Pak Kusnan sebagai berikut:

"Desa Bohar tidak ada tempat isolasi, soalnya tidak ada tempat. Jadinya kalau ada masyarakat yang isolasi dilakukan mandiri dirumah namun tetap ada pantauan dari Desa Bohar." (Wawancara pada 8 Desember 2020)

Keempat melakukan penyemprotan disinfektan dan menyediakan handsanitizer dan tempat cuci tangan. Pada awalnya, penyemprotan disinfektan dilakukan di seluruh Desa Bohar sebanyak dua minggu sekali mulai bulan April hingga bulan Juni. Akan tetapi mulai bulan Juni, penyemprotan disinfektan hanya dilakukan di lingkungan sekitar jika ada masyarakat desa yang dinyatakan reaktif ataupun positif Covid-19. Pemdes Bohar juga 
membagikan masker gratis sebanyak 5.320 masker dengan ketentuan 2 masker per rumah. Berikut merupakan dokumentasi dari penyemprotan disinfektan dan penyediaan handsanitizer yang ada di Desa Bohar:

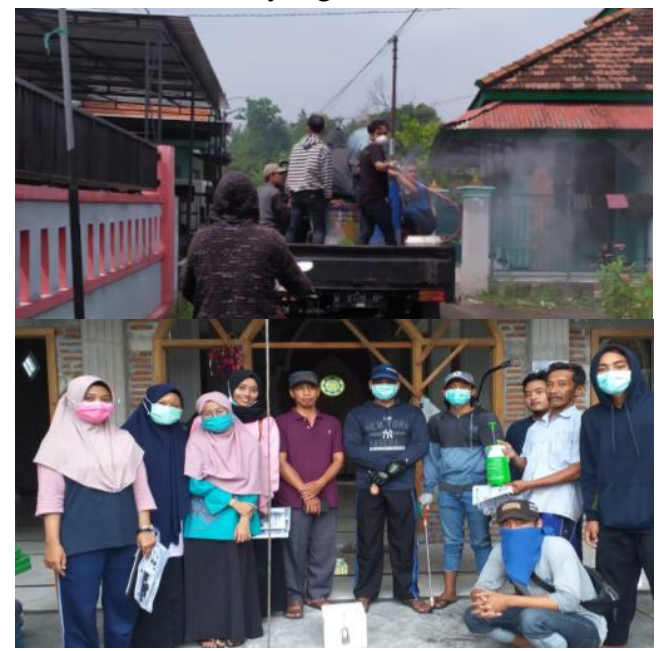

Gambar 2. Proses Penyemprotan Disinfektan dan Penyediaan Handsanitizer

(Sumber: Dokumentasi Peneliti, 2020)

Gambar diatas merupakan kerjasama antara tim relawan dengan Karang Taruna Desa Bohar, dan Remaja Masjid Desa Bohar melakukan penyemprotan disinfektan dan penyediaan tempat cuci tangan serta handsanitizer di tempat umum seperti musholla dan masjid.

Kelima menyediakan alat kesehataan untuk pendetekdian dini dan pencegahan Covid-19. Pengadaan alat-alat kesehatan juga dilakukan Pemdes Bohar sebagai tindakan pencegahan terhadap Covid-19. Alat-alat kesehatan yang dimaksud seperti termometer, disinfektan, masker, baju azmat, handsanitizer, tempat cuci tangan. Jika dilihat dari peralatan kesehatan yang dimiliki oleh Pemdes Bohar sudahlah sesuai dengan protokol kesehatan yang ditetapkan. Akan tetapi, dalam pelaksanaannya kurang begitu diterapkan. Berikut merupakan dokumentasi masyarakat melakukan ibadah di masjid Bohar:

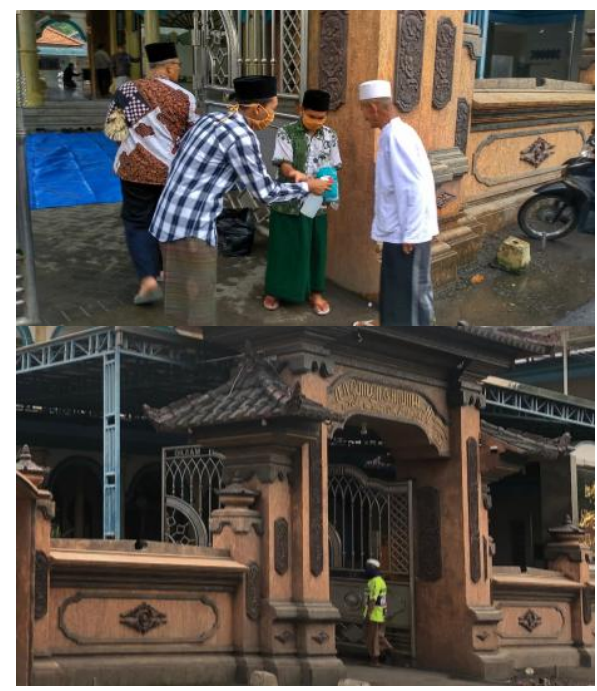

Gambar 3. Pelaksanaan Protokol Kesehatan di Masjid

(Sumber: Dokumentasi Peneliti, 2020)

Dokumentasi diatas menunjukkan bahwa penerapan protokol kesehatan di Desa Bohar berbeda antara yang dulu dengan yang sekarang. Hal ini juga didukung oleh pernyataan dari Elva selaku masyarakat Desa Bohar sebagai berikut:

"Dulu memang saat akan memasuki balai desa diharuskan untuk mencuci tangan dan pengecekan suhu tubuh namun sekarang sudah tidak lagi diterapkan." (Wawancara pada 18 Desember 2020)

Hal tersebut juga peneliti alami langsung ketika melakukan penelitian di balai desa bahwa tidak ada pengecekan suhu tubuh dan pengarahan untuk mencuci tangan ataupun penggunaan handsanitizer sebelum memasuki balai desa. Hal ini menunjukkan bahwa Pemdes Bohar tidak melaksanakan protokol kesehatan di balai desa dan tidak ada tindakan disiplin untuk masyarakat yang melkaukan kegiatan berkumpul seperti ibada di masjid. Padahal pelaksanaan protokol kesehatan sangatlah penting dalam tindakan pencegahan Covid-19.

Keenam penyedian informasi terkait penanganan Covid-19. Penyediaan informasi seperti yang di atas tidak dilakukan oleh Pemdes Bohar baik seperti benner ataupun spanduk. Pak Kusnan menjelaskan sebagi berikut:

"Tidak ada informasi penanganan, jadi kalau ada yang dinyatakan positif maka yang keluarga pasien diharuskan untuk melapor kepada Pemdes Bohar, kemudian akan diteruskan pada tim rumah sakit rujukan." (Wawancara pada 8 Desember 2020)

Ketujuh melakukan deteksi dini dengan melakukan pencatatan keluar dan masuk untuk tamu atau masyarakat yang baru datang dari rantau. Hal ini juga bersinggungan dengan tugas tim relawan yang kedelapan yakni mendirikan Pos Jaga Gerbang Desa (24 Jam). Di Desa Bohar pos jaga didirikan di setiap pintu masuk dusun yang ada di Desa Bohar. Pos jaga di Desa Bohar berjumlah 6 yang berada di Dusun Bohar Selatan, Bohar Timur, Bohar Utara, Bohar Kowong, Bohar Balun, dan Bohar Perumahan. Pencatatan keluar dan masuk akan dilakukan disetiap pos masuk dusun. Hal ini didukung oleh wawancara dengan Pak Kusnan sebagia berikut:

"Dalam setiap posko relawan ada pencatatan keluar-masuk tamu dan kalau ada masyarakat yang kembali dari rantau maka 
diharuskan melakukan isolasi mandiri selama 14 hari." (Wawancara pada 8 Desember 2020)

Berikut merupakan dokumentasi Pos Jaga di Desa Bohar:

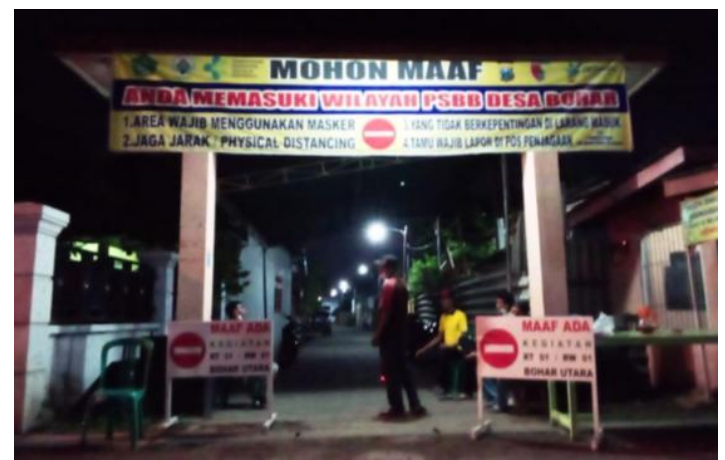

Gambar 4. Pos Jaga Desa Bohar

(Sumber: Dokumentasi Peneliti, 2020)

Dengan adanya pos jaga, pintu untuk akses keluar masuk hanya satu dalam setiap dusun. Hal ini dilakukan oleh pemerintah Desa Bohar selama PSBB diberlakukan di Kabupaten Sidoarjo.

Dan yang terakhir dalam pencegahan Covid-19 ialah memastikan masyarakat untuk tidak melakukan kegiatan berkumpul seperti penikahan atau kegiatan lainnya. Saat ini kegiatan berkumpul seperti pernikahan sudah diperbolehkan namun dengan beberapa persyaratan ketat yang harus diikuti. Pihak pengantin diharuskan untuk melakukan perizinan kepada pemdes yang kemudian akan dilanjutkan untuk perizinan di kepolisian dan yang terakhir diharuskan untuk tes rapid dan mendapat keterangan non-reaktif. Dan selama resepsi pernikahan diharuskan untuk menjaga protokol kesehatan seperti mengnakan masker dan menjaga jarak. Jika hal tersebut tidak dilaksanakan maka akan didenda Rp 50.000.000.

Selain pernikahan, peneliti juga menemukan pengadaan hiburan massa di Desa Bohar yakni pengadaan kompetisi sepak bola. Berdasarkan wawancara dengan pihak desa yang diwakili oleh Pak Kusnan sebagai berikut:

"Pengadaan kompetisi sepak bola tersebut bukan kegiatan dari desa melainkan dari Sekolah Sepak Bola (SSB) Bohar. Pihak SSB Bohar tidak melakukan perizinan mengenai pengadaan kegiatan berkumpul yang semestinya." (Wawancara pada 15 Desember 2020)

Sedangkan pernyataan dari Pak Fahmi selaku ketua SSB Bohar sebagai berikut:

\begin{abstract}
"Kegiatan ini dimaksudkan untuk olahraga bersama sehingga tidak perlu perizinan. Dan jika diperlukan izin pihak SSB akan melakukan perizinan tapi sampai sekarang tidak ada arahan dari orang desa untuk perizinan." (Wawancara pada 18 Desember 2020)
\end{abstract}

Berikut merupakan dokumentasi dari kegiatan kompetisi sepak bola yang diadakan SSB Bohar di lapangan Desa Bohar:

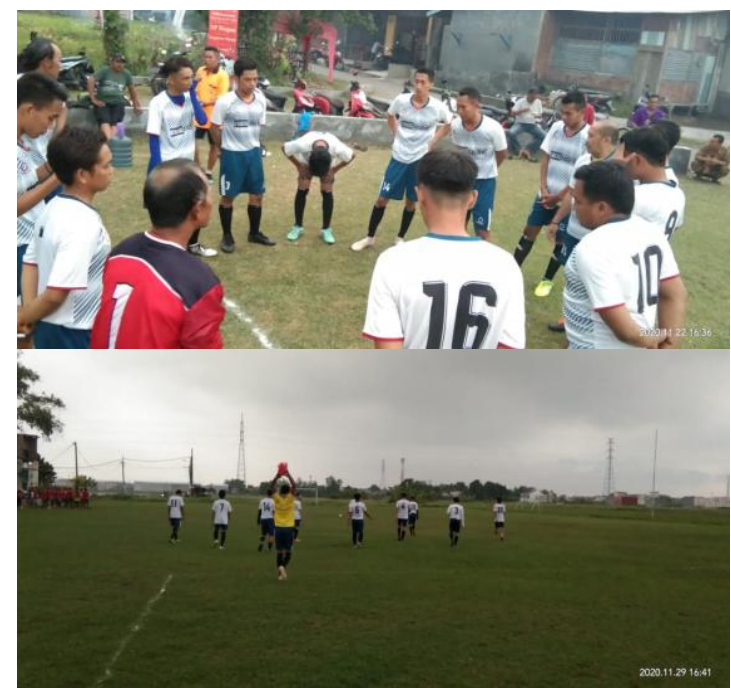

Gambar 5. Kegiatan Kompetisi Sepak Bola Desa Bohar

(Sumber: Dokumentasi Peneliti, 2020)

Dokumentasi diatas menunjukkan bahwa kegiatan kompetisi sepak bola merupakan kegiatan yang menjadi tontonan masyarakat desa, terlebih banyak masyarakat yang tidak mematuhi protokol kesehatan dengan memakai masker dan menjaga jarak. Selain itu, sering kali pertandingan sepak bola yang dilakukan melawan tim dari luar Bohar. Meski sering dilakukan pertandingan, hingga saat ini tidak ada tindakan dari Pemdes Bohar untuk mendisiplinkan kegiatan tersebut.

Selain tindakan pencegahan, tindakan penanganan Covid-19 juga dilakukan diantaranya pertama dengan melakukan kerja sama dengan puskesmas dan rumah sakt rujukan setempat. Dalam hal ini Pemdes Bohar melakukan kerja sama dengan Rumah Sakit Umum Daerah Sidoarjo dan Puskesmas Taman serta berkoordinasi dengan Bidan Desa.

Kedua dengan menyiapkan ruang isolasi Desa. Dalam hal ini Pemdes Bohar tidak dapat menyediakan ruang isolasi khusus karena kurang nya tempat. Sehingga masyarakat melakukan isolasi mandiri namun tetap dengan pegawasan pemdes dan tim medis yang telah bekerja sama. 
Ketiga yakni mengarahkan kepada masyarakat yang pulang dari luar daerah untuk melakukan isolasi mandiri. Dalam tahap ini, Pak Kusnan menerangkan bahwa pemdes Bohar menyerahkan data masuk dan keluar untuk tamu dan masyarakat rantau kepada Rukun Tangga (RT) dan Rukun Warga (RW) yang kemudian akan dilaporkan kepada pemdes Bohar. Namun berbeda halnya dengan yang diterangkan oleh Bu Diah selaku masyarakat Desa Bohar sebagai berikut:

"Pernah ada satu wanita yang merupakan masyarakat desa Bohar pulang dari Kalimantan dan tiba di Bohar sekitar bulan Mei lalu. Orang d sudah mengarahkan untuk melakukan isolasi mandiri, tapi wanita tersebut tidak menurut dan tetap melakukan aktivitas diluar rumah." (Wawancara pada 10 Desember 2020)

Hal ini menunjukkan bahwa pemdes Bohar kurang tegas dalam mendisiplinkan masyarakatnya untuk tetap mematuhi aturan demi kebaikan bersama. Selain itu, partsipasi masyarakat juga kurang karena masyarakat tetap diam melihat kejadian tersebut.

Keempat yakni membantu menyiapkan logistik kepada masyarakat yang melakukan isolasi mandiri. Saat ini, terdapat 7 orang yang melakukan isolasi mandiri di Desa Bohar. Selama masa isolasi pemdes Bohar memberikan bantuan logistik pemantauan yang rutin. Hal ini didukung oleh wawancara dengan Pak Kusnan sebagai berikut:

"Kegiatan logistik diberikan oleh pemdes Bohar kepada keluarga pasien yang kemudian akan diterukan kepada pasien yang melakukan isolasi mandiri. Selain itu, pemdes Bohar juga rutin memantau perkembangan pasien." (Wawancara pada 8 Desember 2020)

Hal diatas di perjelas oleh Bu Lilik selaku Bidan Desa Bohar yang menjelaskan sebagai berikut:

"Pemberian bantuan logistik yang diberikan pemerintah terakhir dilaksanakan pada bulan Juli lalu. Sehingga mulai bulan Agustus hingga saat ini pemenuhan logistik ditanggung oleh masyarakat sendiri." (Wawancara pada 12 Desember 2020)

Kelima yakni menghubungi tim medis untuk tindak lanjut terhadap pasien yang melakukan isolasi mandiri. Dalam hal ini Pemdes Bohar bekerja sama dengan RSUD Sidoarjo dan Puskesmas Taman serta berkoordinasi dengan bidan desa. Bidan desa akan melakukan pengecekan secara rutin kepada pasien yang melakukan isolasi selama 14 hari, sedangkan kebutuhan logistik akan dipenuhi oleh Pemdes Bohar. Selanjutnya, pemdes Bohar akan melakukan laporan kepada RSUD Sidoarjo dan Puskesmas Taman.

Pemanfaatan dana desa dalam pencegahan dan penanganan Covid-19 merupakan salah satu tindakan pemerintah pusat melakukan intervensi atau campur tangan terhadap peerintah desa untuk mengatur prioritas penggunaan dana desa yang diatur dalam Permendesa Nomor 6 Tahun 2020. Menurut (Hughes, 2018) sebagian besar intervensi yang dilakukan pemerintah melalui empat instrumen diantaranya provision (penyediaan) yang berarti pemerintah menyediakan barang atau jasa melalui anggaran, subsidy (subsidi) yang berarti pemberian bantuan oleh pemerintah kepada organisasi untuk menyediakan kebutuhan barang atau jasa yang dibutuhkan pemerintah, production (poduksi) berarti pemerintah memproduksi barang atau jasa yang kemudian akan dijual di pasaran, and regulation (regulasi) yang berarti pemerintah menggunakan kekuatan koersif negara untuk melarang atau mengizinkan kegiatan tertentu. Dari keempat instrumen tersebut yang paling tepat untuk intervensi pemerintah pusat terhadap pemerintah desa dalam penggunaan dana desa. Dalam arti lain, perubahan Permendesa Nomor 11 Tahun 2019 menjadi Permendesa Nomor 6 Tahun 2020 tentang Prioritas Penggunaan Dana Desa.

\section{Pemanfaatan Dana Desa dalam Padat Karya Tunai Desa (PKTD)}

Selama masa pandemi Covid-19, pelaksanaaan PKTD di Desa Bohar dilakukan melalui pendayagunaan sumber daya mansuia. Pendayagunaan yang dimaksud ialah dengan menjaga Pos Jaga Covid-19 selama 24 jam. Pak Kusnan selaku sekretaris Desa Bohar menerangkan sebagai berikut:

"Untuk program PKTD dana desa yang dianggarkan sebesar Rp 40.260.000. PKTD dilaksanakan selama 30 hari dan pekerja PKTD akan dibagi menjadi 3 sif yaitu pagi, sore, dan malam. Desa Bohar memperkerjakan 36 orang dan di bagi jadi 6 pos, jadinya 6 orang dalam setiap posnya. Kemudian untuk upahnya Rp 100.000 per hari sudah termasuk makan 2 kali." (Wawancara pada 15 Desember 2020)

Hal diatas didukung oleh Pak Solikhudin yang merupakan pekerja PKTD sebgaai berikut: 
"Upahnya Rp 70.000 dan mendapat makan 2 kali setiap sifnya. Pemberian upah dilakukan setiap harinya ketika sif kerjanya berakhir. Dan dalam satu sifnya dijaga oleh 2 orang disetiap Pos Jaga." (Wawancara pada 18 Desember 2020)

Berdasarkan keterangan dari Pak Solikhudin diatas sudah sesuai dengan Permendesa Nomor 6 tahun 2020 yang menuliskan bahwa pemeberian honorium PKTD dilaksanakan setiap hari. Berikut merupakan dokumentasi peserta PKTD yang berada di Pos Jaga:

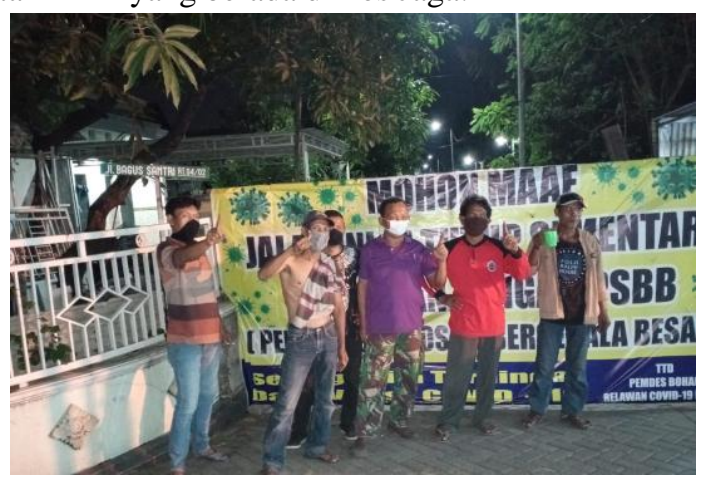

Gambar 6. Pekerja Padat Karya Tunai Desa

(Sumber: Dokumentasi Peneliti, 2020)

Berdasarkan pengamatan peneliti, tidak semua pekerja PKTD berasal dari keluarga miskin atau pengangguran. Bahkan ada pekerja PKTD yang merupakan anak dari salah satu RW di Desa Bohar yang juga dikenal karena memiliki banyak sawah. Hal ini juga didukung oleh wawan cara dengan Pak Sarni salah satu pekerja PKTD sebagai berikut:

\section{"Tidak semua pekerja PKTD dari keluarga miskin atau menganggur. Pokok yang dekat sama sering ngobrol sama orang desa ya itu yang biasanya diajak kerja. Padahal sebenarnya banyak yang lebih butuh." (Wawancara pada 19 Desember 2020)}

Menurut Mubyarto (dalam Heryendi \& Marhaeni, 2013) kemiskinan adalah kondisi dimana serba kekurangan dan terbatasnya kesempatan untuk ikut serta dalam pembangunan. Jika dilihat dengan permasalahan yang ada di Desa Bohar, pekerja PKTD yang berasal dari keluarga berada karena memiliki sawah yang banyak serta merupakan anak dari ketua RW yang mana merupakan masyarakat yang berpartisipasi dalam pembangunan desa.

Hal ini menunjukkan bahwa pemerintah desa Bohar tidak obyektif dalam menentukan pekerja PKTD dan tidak sesuai dengan Permendesa Nomor 6 Tahun 2020 yang menuliskan bahwa PKTD ditujukan untuk masyarakat yang kurang mampu atau pengangguran. Sehingga tujuan dari adanya PKTD untuk meningkat perekonomian dan kesejahteraan masyarakat tidak tepat sasaran

\section{Pemanfaatan Dana Desa dalam Bantuan Langsung Tunai (BLT)}

Sasaran penerima BLT ini merupakan keluarga kurang mampu atau pengangguran yang bukan penerima program bantuan pemerintah seperti PKH, BNPT atau lainnya. Adapun wawancara dengan Pak Kusnan yang merupakan sekretaris Desa Bohar sebagai berikut:

"Penerima BLT ditentukan berdasarkan pendataan yang dilakukan oleh setiap RT dan RW yang kemudian akan di diskusikan dalam Musyawarah Desa (Musdes). Selain itu ada juga validasi data dengan Dinas Ketenaga Kerjaan mengenai PKH dan BNPT dan validasi data kependudukan. Baru setelahnya akan di finalisasi lagi di musdes.“ (Wawancara pada 15 Desember 2020)

Berikut merupakan dokumentasi Musyawarah Desa Bohar:

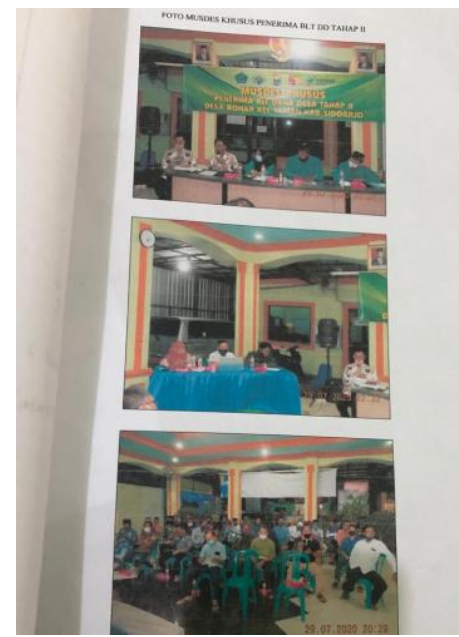

Gambar 7. Musyawarah Desa Bohar

(Sumber: Laporan Pertanggungjawaban BLT II, 2020)

Dari gambar diatas yang mana dilakukannya Musdes untuk setiap validasi dan finalisasi data penerima BLT dalam setiap tahap menjadikan penerima BLT di Desa Bohar selalu berdasarkan data yang baru sehingga dapat mencapai sasaran.

Berdasarkan hal yang dimuat diatas, pendataan yang penerima BLT yang ada di Desa Bohar sudah sesuai dengan Panduan Pendataan BLT- Dana Desa 2020 oleh Kementerian Perencanaan Pembangunan Nasional yakni sebagai berikut:

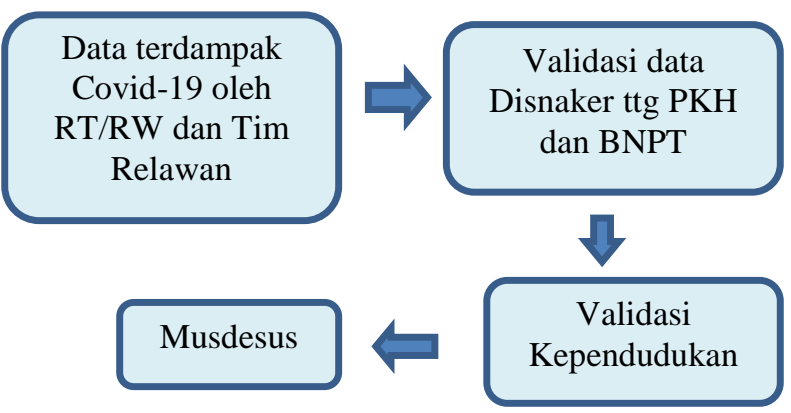


Gambar 8. Tahapan Pemberian BLT

(Sumber: Buku Saku Panduan Pendataan

BLT-Dana Desa, 2020)

Pak Kusnan juga mengatakan bahwa Desa Bohar menerima Dana Desa sejumlah Rp 802.855.000 sehingga perhitungan BLT menurut metode perhitungan pada Permendes Nomor 6 Tahun 2020 sebagai berikut:

$$
\begin{aligned}
\text { BLT } & =30 \% \times \sum \text { Dana Desa } \\
& =30 \% \times \operatorname{Rp} 802.855 .000 \\
& =\operatorname{Rp} 240.856 .500
\end{aligned}
$$

Berdasarkan perhitungan diatas, BLT yang harus diberikan oleh Desa Bohar maksimal Rp 240.856.500. Pemberian BLT di Desa Bohar di bagi dalam 3 gelombang. Gelombang pertama sesuai dengan Permendes Nomor 6 Tahun 2020 yang menyebutkan besaran BLT yang dibagikan per bulan sebesar Rp 600.000 selama 3 bulan. Hal ini diperjelas dengan wawancara Pak Kusnan selaku sekretaris Desa Bohar sebagai berikut:

"Pemberian BLT gelombang pertama ini
dimulai sejak bulan April, Mei, dan Juni
kepada 133 keluarga. Ada 133 keluarga
yang merupakan penerima BLT ini
didasarkan pada survei dari masing-masing
RT dan RW. Dalam gelombang pertama ini
berhasil menyerap anggaran sebanyak Rp
239.400.000." (Wawancara pada 8
Desember 2020)

Berdasarkan wawacara diatas, pemberian BLT gelombang pertama sudah sesuai dengan Permendsa Nomor 6 Tahun 2020 yang menuliskan bahwa dana desa untuk BLT maksimal $30 \%$ dari jumlah dana desa yakni Rp 240.856.500.

Meskipun dalam Permendesa Nomor 6 Tahun 2020 hanya diwajibkan untuk memberikan BLT 3 bulan terhitung sejak bulan April. Pemerintah Desa Bohar tetap memberikan BLT gelombang kedua yang dilaksanakan pada bulan Juli, Agustus, dan September yang didasarkan pada Peraturan Bupati Sidoarjo Nomor 42 Tahun 2020 tentang Perubaan Atas Perbup Nomor 8 Tahun 2020 tentang Tata Cara Perhitungaan dan Pembagian Besaran Dana Desa di Kabupaten Sidoarjo Tahun Anggran 2020. Hal ini didukung dengan keterangan dari Pak Kusnan selaku sebagai berikut:

"Meskipun pemberian BLT menurut Peremendesa Nomor 6 Tahun 2020 sudah terpenuhi, namun dalam Peraturan Bupati Sidoarjo Nomor 42 Tahun 2020 dijelaskan bahwa ada penambahan dalam pemberian BLT yaitu per bulan sebesar Rp 300.000 selama tiga bulan. Untuk BLT gelombang kedua ini diberikan kepada 29 keluarga dan berhasil menyerap anggaran sebesar Rp 26.100.000." (Wawancara pada 8 Desember 2020)

Pemberian BLT ini sangat membantu masyrakat khususnya dimasa pandemi Covid-19 seperti ini. Banyak masyrakat yang mengalami penurunan pemasukan ekonomi atau bahkan yang kehilangan pekerjaan akibat Covid-19. Selain itu, pemberian BLT di Desa Bohar sudah sesuai sasaran karena pendataan yang dilakukan selalu menggunakan data yang baru sehingga tepat sasaran. Hal ini didukung oleh wawancara dengan $\mathrm{Bu}$ Sumarni selaku penerima BLT gelombang kedua sebagai berikut:

"Pemberian BLT sebesar Rp 300.000 sangatlah membantu untuk memenuhi kebutuhan hidup apalagi di masa pandemi seperti ini. BLT sekarang sudah bagus, yang dikasih itu merupakan orang benar-benar kekurangan." (Wawancara pada 8 Desember 2020)

Dan gelombang yang ketiga dilaksanakan pada bulan Oktober, November, dan Desember. Digelombang yang terakhir ini Pemdes Bohar merencanakan jumlah keluarga yang akan menerima BLT sebanyak 21 keluarga dengan besaran yang sama pada gelembang sebelumnya yakni Rp 300.000 per bulannya. Untuk gelombang ketiga ini masih belum dilaksanakan karena dana desa tahap terakhir masih belum disalurkan. Namun, untuk penganggarannya akan dianggarkan sebesar Rp 18.900.000. Berikut merupakan dokumentasi saat pembagian BLT tahap pertama:

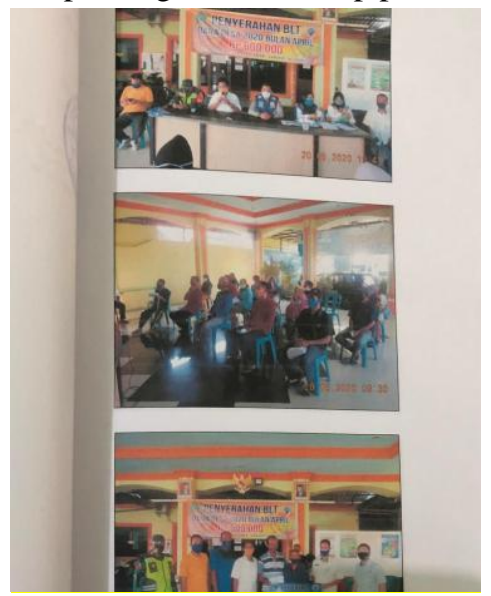

Gambar 9. Pembagian BLT Tahap Pertama

(Sumber: Laporan Pertanggungjawaban BLT I, 2020) 
Dari gambar diatas menunjukkan bahwa pembagian BLT di Desa Bohar dilakukan di Balai Desa Bohar dengan non-tunai dan mematuhi protokol kesehaatn. Hal ini sudah selaras dengan Permendes Nomor 6 Tahun 2020 yang mengaharuskan penyaluran BLT dilakukan secara non-tunai. Adapun keterangan dari Pak Hajir selaku penerima BLT gelombang pertama sebagai berikut:

"Penerimaan BLT sekarang sangat cepat, tidak perlu antri panjang seperti dulu karena langsung melalui bank atau non-tunai. Sehingga untuk kemungkinan terjadinya penyimpangan yang dilakukan pemerintah desa Bohar sangat minim."

\section{PENUTUP}

\section{Simpulan}

Pemanfaatan Dana Desa untuk Pencegahan dan Penanganan Covid-19 di Desa Bohar sejumlah Rp 64.053.440. Untuk melakukan tindakan pencegahan dan penanganan Desa Bohar membentuk tim relawan dan mendirikan pos jaga sejumlah 6 pos dimasing-masing dusun di Desa Bohar. Kegiatan pencegahan yang dilakukan oleh tim relawn Covid-19 masih belum maksimal karena masih banyak kegiatan di Desa Bohar yang tidak mematuhi protokol kesehatan seperti di masjid dan balai desa. Kemudian untuk kegiatan penanganan, Desa Bohar memfasilitasi proses isolasi mandiri dengan bekerja sama dengan RSUD Sidoarjo dan Puskesmas Taman.

Pemanfaatan Dana Desa untuk Padat Kraya Tunai Desa di Desa Bohar sejumlah Rp 40.260.000 masih belum maksimal. Karena dalam pemilihan pekerja PKTD dipilih oleh Pemdes Bohar bukan berdasarkan data keluarga miskin ataupun pengangguran sehingga tidak tepat sasaran.

Pemanfaatan Dana Desa untuk Bantuan Langsuug Tunai di Desa Bohar dilakukan dalam 3 gelombang. Gelombang pertama dilakukan pada bulan April, Mei, Juni dengan bantuan sebesar Rp 600.000 per bulannya. Penerima gelombang pertama sebanyak 133 keluarga. Gelombang kedua dilaksanakan pada bulan Juli, Agustus, September sebesar Rp 300.000 per bulan dengan penerima bantuan sebanyak 29 keluarga. Untuk gelombang ketiga yang seharusnya dilaksanakan pada bulan Oktober, November, dan Desember dengan penerima sebanyak 21 keluarga sebesar Rp 300.000 per bulannya masih belum dilaksakan. Hal ini dikarenakan dana desa tahap terakhir masih belum disalurkan. Pemberian BLT di Desa Bohar sudah dilakukan dengan baik, karena pemberian dilakukan dengan mematuhi protokol kesehatan dan penyaluran dilakukan secara nontunai langsung oleh pihak bank sehingga kemungkinan terjadinya penyimpangan oleh Pemdes Bohar sangatlah kecil.

\section{Saran}

Dalam pemanfaatan dana desa untuk penceghan dan penangganan Covid-19 seharusnya pemdes Bohar melakukan sosialisasi atau pemberian edukasi terkait Covid-19 agar masyarakat benar-benar paham dan terhindar dari Covid-19. Selain itu, meskipun peralatan kesehatan yang dimiliki untuk tindakan pencegahan memanglah sudah lengkap namun dalam pelaksanaannya masih belum diterapkan. Maka dari itu, seharusnya pmerintah desa Bohar juga harus mematuhi protokol kesehatan dan melakukan tindakan yang diperlukan jika ada yang melanggar.

Dalam pemanfaatan dana desa untuk PKTD seharusnya pemerintah desa Bohar lebih obyektif dalam menentukan tenaga kerja dalam program Padat Karya Tunai Desa. Penetuan dilakukan berdasarkan peringkat perekonomian masyarakat yang ada di Desa Bohar bukan berdasarkan kedekatan dengan pemerintah Desa Bohar.

Dalam pemanfaatan dana desa untuk BLT alangkah baiknya jika penerima BLT merupakan keluarga yang berbeda disetiap gelombangnya agar terjadi pemerataan.

\section{DAFTAR PUSTAKA}

Aminah, A., \& Sari, N. (2018). Pengelolaan Dan Pemanfaatan Dana Desa Untuk Pemberdayaan Masyarakat (Studi Kasus Di Gampong Gunong Meulinteung Kecamatan Panga Kabupaten Aceh Jaya). Jurnal Public Policy, 4(1), 24-35.

Astuty, Elgia; Fanida, E. H. (2013). Akuntabilitas Pemerintah Desa Dalam Pengelolaan Anggaran Pendapatan Dan Belanja Desa (Apbdes) (Studi Pada Alokasi Dana Desa Tahun Anggaran 2011 Di Desa Sareng Kecamatan Geger Kabupaten Madiun). Publika, 1(2).

Binar Dwiyanto Pamungkas, Suprianto, S., Usman, U., Sucihati, R. N., \& Fitryani, V. (2020). Penggunaan Dana Desa Pada Masa Pandemi Covid-19 di Kabupaten Sumbawa. Indonesian Journal of Social Sciences and Humanities, 1(2 SE-), 96-108.

Bupati Sidoarjo. (2020). Peraturan Bupati Sidoarjo Nomor 43 Tahun 2020 Tentang Perubahan Atas Peraturan Bupati Nomor 8 Tahun 2020 Tentang Tata Cara Perhitungan dan Pembagian Besaran Dana Desa Di Kabupaten Sidoarjo Tahun Anggaran 2020.

Dian, T. R., \& Ma'ruf, M. F. (2019). Pemberdayaan Masyarakat Melalui Program Padat Karya Tunai (Studi Kasus Desa Plandaan Kecamatan Kedungwaru Kabupaten Tulungagung). Publika, 7(4).

Djalante, R., Lassa, J., Setiamarga, D., Sudjatma, A., Indrawan, M., Haryanto, B., Mahfud, C., Sinapoy, M. S., Djalante, S., Rafliana, I., Gunawan, L. A., 
Surtiari, G. A. K., \& Warsilah, H. (2020). Review and analysis of current responses to COVID-19 in Indonesia: Period of January to March 2020. Progress in Disaster Science, 6, 100091.

Donthu, N., \& Gustafsson, A. (2020). Effects of COVID19 on business and research. Journal of Business Research, 117(June), 284-289.

Fahri, Jalil, A., \& Kasnelly, S. (2020). Meningkatknya angka pengangguran ditengah pandemi (COVID19). Al Mizan:Jurnal Ekonomi Syariah, 2(Desember 2019), 45-60.

Gugus Tugas Percepatan Penanganan Covid-19. (2020). Peta Sebaran. Satuan Tugas Penanganan Covid-19.

Heryendi, W. T., \& Marhaeni, A. A. I. N. (2013). Efektivitas Program Usaha Peningkatan Pendapatan Keluarga Sejahtera (UPPKS) Di Kecamatan Denpasar Barat. Jurnal Ekonomi Kuantitatif Terapan, 6(2), 44281.

Hughes, O. E. (2018). Public Management and Administration : an Introduction (fifth). Red Globe Press.

Karimah, F., Saleh, C., \& Wanusmawatie, I. (2014). Pengelolaan alokasi dana desa dalam pemberdayaan masyarakat (Studi pada Desa Deket Kulon Kecamatan Deket Kabupaten Lamongan). Jurnal Administrasi Publik, 2(4), 597-602.

Kemendagri. (2020). Peraturan Menteri Dalam Negeri Republik Indonesia Nomor 20 Tahun 2020 Tentang Percepatan Penanganan Corona Virus Disease 2019 di Lingkungan Pemerintah Daerah.

Kemenkes RI. (2020). Peraturan Menteri Kesehatan Republik Indonesia Nomor 9 Tahun 2020 Tentang Pedoman Pembatasan Sosial Berskala Besar Dalam Rangka Percepatan Penanganan Corona Virus Disease 2019 (Covid-19). Kementerian Kesehatan RI, 28.

Kementerian Dalam Negeri. (2014). Peraturan Menteri dalam Negeri Nomor 113 Tahun 2014 Tentang Pengelolaan Keuangan Desa. Republik Indonesia.

Kementerian Keuangan. (2020). Permenkeu Nomor 40 Tahun 2020 Tentang Perubahan Atas Permenkeu N0.205/PMK.07/2019 Tentang Pengelolaan Dana Desa Tanggap Covid.

Kementerian Perencanaan Pembangunan Nasional. (2020). Panduan Pendataan Bantuan Langsung Tunai - BLT Dana Desa. E-Book, 1-26.

Lestari, S. E., Suryono, A., \& Domai, T. (2018). Implementasi Kebijakan Pengembangan Kawasan Strategis Cepat Tumbuh (Ksct) Di Kabupaten Pacitan. JPSI (Journal of Public Sector Innovations), 2(1), 10.

Mahmuddin, \& Banurea, D. (2018). Pemanfaatan Dana Desa Dalam Pembangunan Desa (Suatu penelitian di Desa Perolihen Kecamatan Sitellu Tali Urang Jehe, Kabupaten Pakpak Bharat). Jurnal Ilmiah Mahasiswa FISIP Unsyiah, 3, 14.

Menteri Desa, Pembangunan Daerah Tertinggal, dan T. R. I. (2020a). Peraturan Menteri Desa, Pembangunan Daerah Tertinggal, dan Transmigrasi Nomor 6 Tahun 2020 Tentang Perubahan Atas Peraturan Menteri Desa, Pembangunan Daerah
Tertinggal, dan Transmigrasi Nomor 11 Tahun 2019 Tentang Prioritas Penggunaan Dana Desa. Menteri Desa, Pembangunan Daerah Tertinggal, Dam Transmigrasi Republik Indonesia, 53(9), 1689-1699. https://doi.org/10.1017/CBO9781107415324.004 Menteri Desa, Pembangunan Daerah Tertinggal, dan T. R. I. (2020b). SE Kemendes Nomor 8 Tahun 2020 Tentang Desa Tanggap Covid-19.

Pakpahan, A. K. (2020). COVID-19 dan Implikasi Bagi Usaha Mikro, Kecil, dan Menengah. 20(April).

Pemerintah Republik Indonesia. (2020). Peraturan Pemerintah Pengganti Undang-Undang Republik Indonesia Nomor 1 Tahun 2020 tentang Kebijakan Keuangan Negara dan Stabilitas Sistem Keuangan Untuk Penanganan Pandemi Covid-19 dan/atau Dalam Rangka Menghadapi Ancaman Yang Membahayakan Perekonomian N. 1, 46.

Presiden Republik Indonesia. (2014). Undang-Undang Republik Indonesia Nomor 6 Tahun 2014 Tentang Desa.

Presiden Republik Indonesia. (2020). Peraturan Pemerintah Nomor 21 Tahun 2020 tentang Pembatasan Sosial Berskala Besar Dalam Rangka Percepatan Penanganan Coronavirus Disease 2019/COVID-19. 2019(022868), 8.

Putri, C. A. (2020). Ledakan Pengangguran Di RI, 10 Juta Orang Harap-Harap Cemas. CNBC Indonesia.

Sekarsari, R. W., \& Rosida, M. A. (2019). Responsivitas Dinas Penanaman Modal Pelayanan Terpadu Satu Pintu Dan Tenaga Kerja Kota Batu Terhadap Tingginya Tingkat Pengangguran Di Kota Wisata Batu. JPSI (Journal of Public Sector Innovations), 3(1), 40.

Sugiyono. (2015). Metode Penelitian Kualitatif, Kuantitatif, dan $R \& D$. Alfabeta.

Susilawati, S., Falefi, R., \& Purwoko, A. (2020). Impact of COVID-19's Pandemic on the Economy of Indonesia. Budapest International Research and Critics Institute (BIRCI-Journal): Humanities and Social Sciences, 3(2), 1147-1156.

Utama, D. L., Pertiwi, D., \& Muda, I. (2020). Review of Resources Allocation Budget for Funding to Eradicate the COVID-19 Based on the Village Revenue and Expenditure Budget in Indonesia. 7(June), 365-370.

World Health Organization. (2020). Critical preparedness, readiness and response actions for COVID-19. March, 1-3. 